\title{
Some Nutritional and Physical Properties of Different Zambian Market Classes of Bambara Groundnut (Vigna subterranea)
}

\author{
Vincent Nyau ${ }^{1}$, Lukonde Mwelwa-Zgambo ${ }^{1}$, Taonga Chirwa-Moonga ${ }^{1}$, Dorothy Nthani ${ }^{1}$, Shiv Prakash ${ }^{2}$, Jerry \\ Rodrigues $^{3} \&$ Jill Farrant ${ }^{3}$ \\ ${ }^{1}$ Department of Food Science and Nutrition, University of Zambia, Lusaka, Zambia \\ ${ }^{2}$ Department of Chemistry, University of Zambia, Lusaka, Zambia \\ ${ }^{3}$ Department of Molecular and Cell Biology, University of Cape Town, 7701 Rondebosch, South Africa \\ Correspondence: Vincent Nyau, Department of Food Science and Nutrition, University of Zambia, Lusaka, \\ Zambia. E-mail: vincentnyau@yahoo.co.uk
}

Received: October 19, 2019

Accepted: November 28, 2019 Online Published: December 7, 2019

doi:10.5539/jfr.v9n1p34

URL: https://doi.org/10.5539/jfr.v9n1p34

\begin{abstract}
Selected nutritional and physical properties of the two commonly cultivated Zambian market classes of Bambara groundnut (red and brown) were investigated to establish their end-user traits. Nutritional (essential amino acids, proximate and mineral compositions) and physical (hydration capacity, hydration index, swelling capacity, swelling index and 100 seed mass) properties were investigated using established standard methods. All the essential amino acids were present in both the red and brown Bambara groundnuts. The highest amount was recorded for leucine $(9.7 \mathrm{~g} / 100 \mathrm{~g}$ protein) in the brown Bambara groundnut and least for methionine $(1.2 \mathrm{~g} / 100 \mathrm{~g}$ protein) in the red market class. All the essential amino acids except methionine in the brown Bambara groundnut market class were above the recommended WHO/FAO provisional requirements for children $(2-5$ years) and adults. The crude protein values ranged from 14.62-18.55 g/100g, total ash $(4.21-4.29 \mathrm{~g} / 100 \mathrm{~g})$, crude fibre $(2.79-5.33 \mathrm{~g} / 100 \mathrm{~g})$, fat $(6.28-6.54 \mathrm{~g} / 100 \mathrm{~g})$, moisture $(8.95-9.13 \mathrm{~g} / 100 \mathrm{~g})$ and carbohydrate $(59.23$ $-60.34 \mathrm{~g} / 100 \mathrm{~g}$ ). Potassium was found to be the most concentrated mineral in both market classes, followed by phosphorous, magnesium and calcium, while lead, mercury and arsenic were not detected. The swelling capacity, swelling index, hydration capacity, and hydration index of the two market classes of Bambara groundnuts were not significantly different, whereas their 100 seed mass was significantly different, with the brown recording the highest.
\end{abstract}

Keywords: Bambara groundnut, amino acid composition, proximate and mineral composition, physical properties

\section{Introduction}

Bambara groundnut (Vigna subterranean) is traditionally one of the most important food resources among peasant farmers in Zambia and other countries in the Sub-Sahara region. The crop has however not been embraced by the commercial farmer and its annual production levels are generally low. Inadequate supplies and high shortages of food in the world, particularly in developing countries necessitate the search for new sources (Mahala \& Mohammed, 2010). According to Mkandawire (2007), most food requirements are provided by fewer than 20 crop species, and there remains a vast repository of many hundreds of underutilised species that have been grown locally for centuries. These have the potential to contribute to the food and nutritional security of the world's poorest people.

Previous studies on Bambara groundnuts have reported that the crop has several advantages over other species in terms of nutritional quality and can withstand adverse environmental conditions. The crop has a number of production advantages in that it can yield highly on poor soils with little rainfall, as well as produce substantial yields under better conditions (Mkandawire, 2007). Linnemann (1990) described Bambara groundnut as nutritionally superior to other legumes and a preferred food crop for many local people. A study by Nyau, Prakash, Rodriques and Farrant (2017) further demonstrated that Bambara groundnuts exhibit enhanced nutraceutical profiles in cooked form.

This study was carried out to generate scientific baseline data on physical and nutritional end-user traits of the 
red and brown market classes of Bambara groundnuts commonly grown in Zambia. This baseline data is important as it could possibly facilitate utilization of this neglected crop as a food source. The nutrition related parameters studied included essential amino acids, mineral content, moisture, ash, crude protein, crude lipid, crude fibre and total carbohydrate compositions. Physical properties that were investigated included 100 seed mass, water hydration capacity, swelling capacity, hydration index, and swelling index respectively. These data are valuable when it comes to the utilization and exploitation of orphaned crops such as Bambara groundnut by breeders, food processors, nutritionists, farmers and policy makers. Water hydration capacity, swelling capacity, hydration index, and swelling index give valuable tips in grain processing as they are correlated with cooking time (Tazazu \& Emire, 2010). The 100 seed mass is also an important characteristic that is well correlated with grain yield and therefore useful in selection for yield (Fageria, Baligar, Moreira, \& Aquino Portes, 2010)

\section{Materials and Methods}

\subsection{Sample Collection}

The Bambara groundnut seed samples were sourced from farmers in the Eastern region of Zambia at harvest. The seeds were cleaned by winnowing to remove all external physical materials. Each market class of Bambara groundnut was collected in batches of $0.5 \mathrm{~kg}$ from 15 farmers to ensure that the samples were representative.

\subsection{HPLC Amino Acid Analysis}

Quantitative analysis of essential amino acids was performed on Waters 2707 Module HPLC system attached to a PDA using the procedure described by Dhillon et al. (2014) with slight modifications. After acid hydrolysis, the samples were derivatised with o-phthalaldehyde (OPA) and transferred to maximum recovery vials. The vials were heated for $10 \mathrm{~min}$ in a water bath at $55^{\circ} \mathrm{C}$ before separation of amino acids using the HPLC. About $10 \mu \mathrm{L}$ sample was injected into a cation-exchange resin column C18 $(3.9 \mathrm{~mm} \mathrm{X} 150 \mathrm{~mm}$ ) using auto sampler (Waters 2707). The Waters AccQ Tag Eluent A Concentrate (WAT052890) was diluted to $10 \%$ in Milli-Q water and used as eluent $\mathrm{A}$, and $60 \%$ acetonitrile as eluent $\mathrm{B}$ in a separation gradient with a flow rate of $1 \mathrm{~mL} / \mathrm{min}$. The separation gradient used was 0-2 $\min (100 \% \mathrm{~A})$, and $2 \min (98 \% \mathrm{~A}), 15 \min (93 \% \mathrm{~A}), 19 \min (90 \% \mathrm{~A}), 32 \mathrm{~min}$ (67\% A), $38 \mathrm{~min}(0 \% \mathrm{~A})$ and $56 \mathrm{~min}(100 \% \mathrm{~A})$. The amino acids were detected using PDA at $254 \mathrm{~nm}$ with the column conditions set at $37{ }^{\circ} \mathrm{C}$. The amino acid peaks were acquired using Empower Pro software ${ }^{\circledR}$ by Waters Corporation (2005-08) and were calculated based on amino acid standards. The concentrations of individual essential amino acids were obtained from linear regression equations of the standard curves and expressed as $\mathrm{g} / 100 \mathrm{~g}$ crude protein.

\subsection{Proximate Composition}

The grounded Bambara seed samples were analysed for crude moisture, crude fat, crude protein, total ash and crude fiber using AOAC official methods of 934.01, 920.39 (A), 984 (A - D), 942.05 and 978.10 respectively (AOAC, 2006). Total carbohydrate content was calculated by difference as described in equation 1 :

Carbohydrate content $(\%)=100-[$ crude protein content $(\%)+$ crude fat content $(\%)+$ total ash $(\%)+$ crude fibre $(\%)+$ crude moisture content $(\%)]$

\subsection{Mineral Analysis}

The mineral content of Bambara groundnut was determined using three methods. The GBC Atomic Absorption Spectrophotometer was used to measure the contents of calcium and magnesium while potassium and sodium were assayed using a Corning 410 flame photometer (Sena et al., 1998). Technicon Auto-analyzer methodology was used to measure the phosphorus content (Lockett, Calvet, \& Grivetti, 2000). The Perkin-Elmer 2001 Model Inductively Coupled Plasma Mass Spectrometry (ICP-MS) was used for assaying iron, zinc, copper, manganese, lead, selenium and arsenic. About $2 \mathrm{~g}$ of the grounded seed was used for each determination and the experiment was performed in triplicate.

\subsection{Hydration, Swelling Capacity and Indices, and 100 Seed Mass}

Hydration and swelling capacities were established following the method described by Bishnoi and Khetarpaul (1993); Tazazu and Emire (2010). One hundred seeds were counted, their weight noted, followed by transferring them into a measuring cylinder to which $100 \mathrm{ml}$ of water was added. The cylinder was left at room temperature for 24 hours with its open end covered with aluminium foil. After 24 hours, all the water was drained out from the cylinder content, and the filter paper was used to remove excess water from the seeds. Hydrated seeds were reweighed and their weight noted. Hydration capacity per seed was calculated by dividing the mass gained by the seeds after hydration, by the number of seeds, while the hydration index was computed as the ratio of average hydration capacity per seed and the mass of one seed. For swelling capacity, 100 seeds were counted, 
put in the measuring cylinder containing $100 \mathrm{ml}$ of water and their initial volume noted. The seeds were then left to hydrate for 24 hours as described above. The volume of the soaked seeds was noted in the graduated cylinder after 24 hours. Swelling capacity per seed was calculated as the volume gained by the seeds divided by the number of the seeds, while the swelling index was computed as the ratio of the swelling capacity per seed to the volume of one seed. The 100 seed mass was determined by counting 100 seeds and noting their mass.

\subsection{Statistical Analysis}

Data were analysed using S-PLUS 6 Windows Professional 2001. The results were presented as mean values \pm standard deviation. The two-sample t-test was used to compare the means for the various Bambara attributes investigated, and values at $p<0.05$ were considered statistically significant.

\section{Results and Discussion}

\subsection{Essential Amino Acid Composition}

Essential amino acids composition ( $\mathrm{g} / 100 \mathrm{~g}$ crude protein) of the red and brown market classes of Bambara groundnuts are presented in Table 1. Generally, all essential amino acids were present in both the red and brown Bambara groundnuts. The highest amount was recorded for leucine $(9.7 \mathrm{~g} / 100 \mathrm{~g}$ protein) in the brown Bambara groundnut and least for methionine $(1.2 \mathrm{~g} / 100 \mathrm{~g}$ protein) in the red market class. The total essential amino acids were found to be 55 and $57 \mathrm{~g} / 100 \mathrm{~g}$ protein for the brown and red Bambara groundnuts, respectively. These values are above the total amino acid content ( $46 \mathrm{~g} / 100 \mathrm{~g}$ protein) reported by Abdualrahman, Ali, Elkhalifa, and Ma (2015) for Sudanese Bambara groundnut. All the essential amino acids, except methionine in the brown Bambara groundnut market class, were above the recommended WHO/FAO, (2007) essential amino acid requirement for children ( $2-5$ years) and adults (Table 1$)$. This observation suggests that only methionine would require supplementation in the Bambara groundnut based diet. Leucine was found to be the most concentrated essential amino acid in both market classes and this has been reported previously for Bambara groundnuts by Aremu, Olaleke, Akintayo and Emmanuel (2006). Methionine was found to be the least concentrated essential amino acid in both market classes as reported previously by Aremu, Olaleke, Akintayo and Emmanuel (2006). The presence of all essential amino acids in both the brown and red market classes of Bambara groundnuts suggests that this underutilized legume could be an alternative source of protein in local dishes especially in rural and peri-urban areas where child malnutrition is highly prevalent. According to Masiye, Chama, Chitah and Jonsson (2010), malnutrition is wide spread among children in Zambia and falls disproportionately on rural children. Increased utilization of Bambara groundnut could enhance dietary diversity and help to combat most nutritional disorders given the variety of products that can be prepared from it. Mumbaiwa, Fogliano, Chidewe and Linnemann (2016) reported a number of preparation methods for Bambara groundnuts including cooking with alkaline salts, milling, roasting, fermentation, and malting.

Table 1. Essential amino acids (g/100 g crude protein) of Bambara groundnuts and the recommended FAO/WHO essential amino acids Provisional Pattern

\begin{tabular}{lllll}
\hline \multirow{2}{*}{ EAA } & \multicolumn{2}{l}{ FAO/WHO* } & Brown Bambara & $\begin{array}{l}\text { Red Bambara } \\
\text { groundnut }\end{array}$ \\
\cline { 2 - 5 } groundnut & Child & Adult & gron \\
\hline Threonine & 3.4 & 0.9 & $3.9^{\mathrm{a}}$ & $4.5^{\mathrm{b}}$ \\
Valine & 3.5 & 1.5 & $6.4^{\mathrm{a}}$ & $5.6^{\mathrm{b}}$ \\
Methionine & 2.7 & 1.7 & $1.2^{\mathrm{a}}$ & $2.8^{\mathrm{b}}$ \\
Isoleucine & 2.8 & 1.3 & $4.9^{\mathrm{a}}$ & $4.8^{\mathrm{a}}$ \\
Leucine & 6.6 & 1.9 & $8.8^{\mathrm{a}}$ & $9.7^{\mathrm{b}}$ \\
Tryptophan & 1.1 & 0.5 & $\mathrm{ND}$ & $\mathrm{ND}$ \\
Phenylanine & 6.3 & 1.9 & $6.4^{\mathrm{a}}$ & $6.6^{\mathrm{a}}$ \\
Histidine & 1.9 & 1.6 & $8.4^{\mathrm{a}}$ & $6.0^{\mathrm{b}}$ \\
Lysine & 5.8 & 1.6 & $7.8^{\mathrm{a}}$ & $8.5^{\mathrm{b}}$ \\
Arginine & - & - & $7.2^{\mathrm{a}}$ & $8.4^{\mathrm{b}}$ \\
\hline
\end{tabular}

EAA $=$ Essential amino acid. ND $=$ not determined. *Source: FAO/WHO (2007)

Values in the same row for the market classes of Bambara groundnuts with different superscripts were significantly $(p<0.05)$ different, and $\mathrm{n}=1$.

\subsection{Proximate Composition of the Seeds}

The results on proximate composition of the Bambara seeds are presented in Table 2. The protein content of the 
red market class ranged between $16-21 \%$, and this was similar to that reported by Brough and Azam-Ali (1992); Brough, Taylor and Azam-Ali (1993); Purseglove, (1992), but much higher than that reported by Aremu, Olaleke, Akintayo and Emmanuel (2006). Contrary to this, the brown market class had a lower protein content of $14.62 \%$ compared to the red, which was also lower than other reported literature. This lower protein value could be attributed to the genotype and possibly the environmental conditions in which they were grown (Salunkhe, Kadon, \& Charan, 1985).

The carbohydrate content of both the red and brown market classes was similar to that reported by Purseglove (1992) in the range of $50-60 \%$, but slightly lower than that reported by Aremu, Olaleke, Akintayo and Emmanuel (2006). However, when compared to Azam-Ali (1992), the carbohydrate contents of the red and brown market classes were higher. The ash content for both market classes was higher than that reported by Mahala and Mohammed (2010) and this difference could be attributed to differences in soil types (Mesquita, Corrêa, Abreu, \& Lima, 2007). The fat concentrations in the current study were similar to those reported by Purseglove, (1992); Ijarotimi and Esho (2009) and were in the range of $4.5-6.5 \%$.

Table 2. Proximate composition ( $\mathrm{g} / 100 \mathrm{~g} \mathrm{DW}$ a) of the whole seed sample

\begin{tabular}{lll}
\hline \multirow{2}{*}{ Property } & \multicolumn{2}{l}{ Market classes of Bambara groundnuts } \\
\cline { 2 - 3 } & Red & Brown \\
\hline Moisture & $9.05 \pm 1.26^{\mathrm{a}}$ & $9.13 \pm 0.71^{\mathrm{a}}$ \\
Crude protein & $18.55 \pm 1.55^{\mathrm{a}}$ & $14.62 \pm 0.01^{\mathrm{b}}$ \\
Total ash & $4.21 \pm 0.68^{\mathrm{a}}$ & $4.29 \pm 0.51^{\mathrm{a}}$ \\
Fat & $6.54 \pm 0.38^{\mathrm{a}}$ & $6.28 \pm 0.77^{\mathrm{a}}$ \\
Crude fibre & $2.79 \pm 0.01^{\mathrm{a}}$ & $5.33 \pm 0.37^{\mathrm{b}}$ \\
Carbohydrates & $59.23 \pm 3.11^{\mathrm{a}}$ & $60.34 \pm 0.81^{\mathrm{a}}$ \\
\hline
\end{tabular}

${ }^{\mathrm{a}}$ Values except moisture content are expressed in dry weight basis, DW = Dry weight

Means \pm standard deviation, $\mathrm{n}=3$, means in the same row with different superscripts were significantly ( $p$ $<0.05)$ different.

\subsection{Mineral Composition of the Seeds}

The results for various mineral contents of the two market classes of Bambara groundnuts are presented in Table 3. Potassium was the most abundant mineral in both the red and brown market classes and ranged from 16282 $16670 \mathrm{mg} / \mathrm{kg}$ DW. This was followed by phosphorous (3221 -3398 mg / kg DW), magnesium (2024 -2054 mg / kg DW) and calcium (516-593 mg / kg DW), respectively. Other minerals such as iron, copper and manganese were found in very low quantities, while mercury, lead and arsenic were undetected in both samples. The potassium concentrations were within the range of $15780-17420 \mathrm{mg} / \mathrm{kg} \mathrm{DW}$, reported by Amarteifio, Karikari and Modise (2002) for Bambara groundnut landraces from Botswana. When the other minerals were compared with previous literature, several differences in concentration were observed from those reported by Amarteifio, Tibe and Njogu (2006); Amarteifio et al. (2002); Kemo (2000); Ijarotimi and Esho (2009). Mineral content of agricultural products varies with geographical location and agricultural practices and therefore, the differences seen in mineral content could possibly be attributed to these factors (Amarteifio et al., 2006). Information gathered from the local people where sampling of the seeds was done revealed that the Bambara groundnut landraces were normally intercropped with maize and no chemicals or fertilizers are used. Further, most growers in Zambia prefer growing the Bambara groundnuts in sandy loam soil that is well drained. Thus, the differences in agricultural practices that are seen from one growing region of Africa to another could possibly be one of the key factors affecting mineral content of Bambara nuts and other crops in general.

The ratios of sodium to potassium $(\mathrm{Na} / \mathrm{K})$ and calcium to phosphorous $(\mathrm{Ca} / \mathrm{P})$ were also computed and are presented in Table 3. The $\mathrm{Na} / \mathrm{K}$ ratio was 0.0015 for the red market class and 0.0023 for the brown market class, whereas the $\mathrm{Ca} / \mathrm{P}$ ratio was 0.15 for the red market class and 0.18 for the brown market class of Bambara groundnuts respectively. According to the report by Aremu, Olaleke, Akintayo and Emmanuel (2006), the Na/K ratio in the body is of great significance for the prevention of high blood pressure and it is recommended to be less than one. The findings on the $\mathrm{Na} / \mathrm{K}$ ratio in the current study suggest that both the red and the brown market classes of Bambara groundnuts would fit in the category of foods for high blood pressure prevention, given that both their $\mathrm{Na} / \mathrm{K}$ ratios are less than one. The $\mathrm{Ca} / \mathrm{p}$ ratios for both the red and brown market classes of Bambara groundnuts were lower than what was previously reported by Aremu, Olaleke, Akintayo and Emmanuel (2006), but suffice to say that the two legumes would still serve as alternative sources of calcium and phosphorous for 
the body.

Table 3. Mineral composition (mg / kg DW) of the whole seed sample

\begin{tabular}{lll}
\hline Minerals & \multicolumn{2}{l}{ Market classes of Bambara groundnuts } \\
\cline { 2 - 3 } & Red & Brown \\
\hline Calcium & $516.6 \pm 0.59^{\mathrm{a}}$ & $593.7 \pm 0.67^{\mathrm{b}}$ \\
Magnesium & $2024.4 \pm 0.20^{\mathrm{a}}$ & $2054 \pm 0.21^{\mathrm{b}}$ \\
Potassium & $16670.1 \pm 1.08^{\mathrm{a}}$ & $16282.2 \pm 1.56^{\mathrm{b}}$ \\
Phosphorous & $3398.5 \pm 0.03^{\mathrm{a}}$ & $3221.1 \pm 0.02^{\mathrm{b}}$ \\
Sodium & $26.2 \pm 1.97^{\mathrm{a}}$ & $38.4 \pm 2.89^{\mathrm{b}}$ \\
Iron & $27.25 \pm 1.3^{\mathrm{a}}$ & $20.97 \pm 1.9^{\mathrm{b}}$ \\
Arsenic & $\mathrm{ND}$ & $\mathrm{ND}$ \\
Zinc & $19.02 \pm 1.4^{\mathrm{a}}$ & $18.45 \pm 1.0^{\mathrm{a}}$ \\
Lead & $\mathrm{ND}$ & $\mathrm{ND}$ \\
Copper & $5.51 \pm 2.4^{\mathrm{a}}$ & $5.12 \pm 1.0^{\mathrm{a}}$ \\
Manganese & $13.87 \pm 2.3^{\mathrm{a}}$ & $19.62 \pm 1.9^{\mathrm{b}}$ \\
Mercury & $\mathrm{ND}$ & $\mathrm{ND}$ \\
Ca/P & 0.15 & 0.18 \\
$\mathrm{Na} / \mathrm{K}$ & 0.0015 & 0.0023 \\
\hline
\end{tabular}

Means \pm standard deviation, $\mathrm{n}=3$, means in the same row with different superscripts were significantly ( $p<$ $0.05)$ different.

$\mathrm{Ca} / \mathrm{P}=$ Calcium to Phosphorus, $\mathrm{Na} / \mathrm{K}=$ Sodium to Potassium ratio.

$\mathrm{ND}=$ Not detected

DW $=$ Dry Weight

\subsection{Physicochemical Properties of the Seeds}

Table 4 summarizes the physicochemical properties of the red and brown Bambara groundnuts. There were no significant differences $(p>0.05)$ observed in the swelling capacity, swelling index, hydration capacity, and hydration index of the two market classes. Previous studies by Tazazu and Emire (2010); Bishnoi and Khetarpaul (1993) reported an inverse relationship between these parameters and the cooking time. Lower values for these parameters suggest longer cooking time. Hence, the red and brown Bambara groundnuts would most likely have comparable cooking times. The brown Bambara groundnut market class had a higher 100 seed mass compared to the red and the difference between the two was significant $(\mathrm{p}<0.05)$. This suggests that in terms of yield and marketed weight, the brown market class would be a better choice.

Table 4. Physicochemical properties of the seeds

\begin{tabular}{lll}
\hline Property & \multicolumn{2}{l}{ Market classes of Bambara groundnuts } \\
\cline { 2 - 3 } & Red & Brown \\
\hline 100 seed mass (g / 100 seeds) & $72.922 \pm 2.969^{\mathrm{a}}$ & $88.812 \pm 1.979^{\mathrm{b}}$ \\
Hydration capacity (g / seed) & $0.173 \pm 0.014^{\mathrm{a}}$ & $0.176 \pm 0.006^{\mathrm{a}}$ \\
Hydration index & $0.125 \pm 0.004^{\mathrm{a}}$ & $0.120 \pm 0.008^{\mathrm{a}}$ \\
Swelling capacity (ml / seed) & $0.180 \pm 0.036^{\mathrm{a}}$ & $0.184 \pm 0.031^{\mathrm{a}}$ \\
Swelling index & $0.120 \pm 0.005^{\mathrm{a}}$ & $0.122 \pm 0.002^{\mathrm{a}}$ \\
\hline
\end{tabular}

Means \pm standard deviation, $\mathrm{n}=3$, means in the same row with different superscripts were significantly $(\mathrm{p}<0.05)$ different.

\section{Conclusion}

The study has shown that Bambara groundnuts have considerable amino acid, macronutrients and mineral profiles that could be exploited for use in local dishes especially in rural areas of developing countries where child malnutrition is highly prevalent. The hydration and swelling behaviours for the two market classes are similar, suggesting comparable cooking times. The brown is of higher quality than the red with regards to seed mass. 


\section{References}

Abdualrahman, M. A. Y., Ali, A. O., Elkhalifa, E. A., \& Ma, H. (2015). Chemical, Minerals, Fatty Acid and Amino Acid Compositions of Sudanese Traditional Khemiss-Tweria Supplemented with Peanut and Bambara Groundnuts. American Journal of Food Technology, 10(3), 100-108. https://doi.org/10.3923/ajft.2015.100.108

Amarteifio, J. O., Karikari, S. K., \& Modise, O. J. (2002). The proximate and mineral composition of six landraces of Bambara groundnuts. Tropical Science, 42, 188-191.

Amarteifio, J. O., Tibe, O., \& Njogu, R. M. (2006). The mineral composition of Bambara groundnuts (Vigna subterranean (L) Verdc) grown in Southern Africa. Africa Journal Biotechnology, 5(23), 2408-2411.

AOAC. (2006). Methods of Analysis - Official methods 923.03, 923.05, 925.09, 962.09, and 979.09. Association of Official Analytical Chemists, (Vol. II 17th edition) of AOAC International, Washington, DC, USA.

Aremu, M., Olaleke, O. O., \& Akintayo, T. E. (2006). A Comparative study on the Chemical and Amino Acids Composition of some Nigerian Under-Utilzed Legume flours. Pakistan Journal of Nutrition, 5(1), 34-38. http://dx.doi.org/10.3923/pjn.2006.34.38

Azam-Ali, S. N. (1992). Evaluating the potential of Bambara groundnuts (Vigna subterranean L. Verdc) as a food crop for semi-arid Africa. In: a paper given at the proceedings of the third SADC Regional Conference on land and water Management, Harare, October, 1997.

Bishnoi, S., \& Khetarpaul, N. (1993). Variability in physico-chemical properties and nutrient composition of different pea cultivars. Food Chemistry, 47, 371-373. https://doi.org/10.1016/0308-8146(93)90179-J

Brough, S. H., Taylor, A. J., \& Azam-Ali, S. N. (1993). The potential of Bambara groundnuts (Vigna subterranea) in vegetable milk production and basic protein functionality systems. Food Chemistry, 47, 277-283. https://doi.org/10.1016/0308-8146(93)90161-8

Dhillon, M. K., Sandeep, K., \& Gujar, G. T. (2014). A common HPLC-PDA method for amino acid analysis in insect and plants. Indian Journal of Experimental Biology, 52, 73-79. http://nopr.niscair.res.in/handle/123456789/25161

Fageria, N. K., Baligar, V. C., Moreira, A., \& Aquino, P. T. (2010). Dry bean genotypes evaluation for growth, yield components and phosphorus use efficiency. Journal of Plant Nutrition, 33(14). https://doi.org/10.1080/01904167.2010.519089

FAO/WHO. (2007). Protein and amino acid requirements in human nutrition. Report of a Joint WHO/FAO/UNU Expert Consultation, WHO technical report series no. 935. Geneva, Switzerland: World Health Organization.

Ijarotimi, O. S., \& Esho, T. R. (2009). Comparison of nutritional composition and anti-nutrient status of fermented, germinated and roasted bambara groundnut seeds (vigna subterranea). British Food Journal, 111(4), 376-386. https://doi.org/10.1108/00070700910951515

Kemo, M. S. (2000). Chemical composition of four landraces of Bambara groundnuts grown in Botswana. B.Sc thesis, Botswana College of Agriculture.

Layman, D. K., \& Walker, D. A. (2006). Potential importance of leucine in the treatment of obesity and the metabolic syndrome. The Journal of Nutrition, 136(1), 319S-323S. https://doi.org/10.1093/jn/136.1.319S

Linnemann, A. R., \& Azam-Ali, S. N. (1993). Bambara groundnuts (Vigna subterranea). In: J. T. Williams (Eds.), Underutilized Crops: Pulses and Vegetables (pp. 13-57). London: Chapman \& Hall.

Lockett, C. T., Calvet, C. C., \& Grivetti, L. E. (2000). Energy and micronutrient composition of dietary and medicinal wild plants consumed during drought. Study of rural Fulani, Norheastern Nigeria. International Journal Food Science and Nutrition, 51, 195-208. https://doi.org/10.1080/09637480050029700

Mahala, A. G., \& Mohammed, A. A. A. (2010). Nutritive Evaluation of Bambara Groundnuts (Vigna subterranean) Pods, Seeds and Hull as Animal Feeds. Journal of Applied Sciences Research, 6(5), 383-386. Retrieved from http://khartoumspace.uofk.edu/123456789/21145

Masiye, F., Chama, C., Chitah, B., \& Jonsson, D. (2010). Determinants of Child Nutritional Status in Zambia: An Analysis of a National Survey. Zambia Social Science Journal, 1(1), 29-42. Retrieved from https://scholarship.law.cornell.edu/zssj/vol1/iss1/4

Mesquita, F. R., Corrêa, A. D., Abreu, C. M. P., Lima, R. A. Z., \& Abreu, A. F. B. (2007). Linhagens de feijão 
(Phaseolus vulgaris L.): composição química e digestibilidade protéica. Ciência e Agrotectecnologia, Lavras, 31(4), 1114-1121. http://dx.doi.org/10.1590/S1413-70542007000400026

Mkandawire, C. H. (2007). Review of Bambara Groundnuts (Vigna subterranean (L.) Verdc.) Production in Sub-Sahara Africa. Agricultural Journal, 2(4), 464-470. Retrieved from http://medwelljournals.com/abstract/?doi=aj.2007.464.470

Mubaiwa, J., Fogliano, V., Chidewe, C., \& Linnemann, N. R. (2016). Hard-to-cook phenomenon in bambara groundnut (Vigna subterranea (L.) Verdc.) processing: Options to improve its role in providing food security. Food Reviews International, 33(2), 167-194. https://doi.org/10.1080/87559129.2016.1149864

Nyau, V., Prakash, S., Rodriques, J., \& Farrant, J. (2017). Domestic cooking effects of Bambara groundnuts and Common Beans in the Antioxidant Properties and Polyphenol Profiles. Journal of Food Research, 6(2), 24-37. https://doi.org/10.5539/jfr.v6n2p24

Purseglove, J. W. (1992). Tropical Crops (Dicotyledons). Longman House Burnt Mill, Harlow, Essex CM20 2JE England.

Salunkhe, D. K., Kadon, S. S., \& Charan, J. K. (1985). Postharvest Biotechnology of food legumes. Bocaranton F.L. CRC press.

Sena, L. P., Van der jagt, D. J., Rivera, C., Tsin, I., Muhamadu, A. T. C., Mahamadou, O., Millson, M., Pastuszyn, A., \& Glew, R. H. (1998). Analysis of nutritional components of eigt famine foods of the republic of Niger. Plant Foods Human Nutrition, 52, 17-30. https://doi.org/10.1023/A:1008010009170

Tazazu, H., \& Emire, S. A. (2010). Chemical composition, physicochemical and functional properties of Lupin (Lupinus albus) seeds grown in Ethiopia. African Journal of Food, Agriculture, Nutrition and Development, 10(8), 3029-3046. https://doi.org/10.4314/ajfand.v10i8.60895

Tessier, A. J., \& Chevalier, S. (2018). An Update on Protein, Leucine, Omega-3 Fatty Acids, and Vitamin D in the Prevention and Treatment of Sarcopenia and Functional Decline. Nutrients, 10(8), 1-17. https://doi.org/10.3390/nu10081099

\section{Copyrights}

Copyright for this article is retained by the author(s), with first publication rights granted to the journal.

This is an open-access article distributed under the terms and conditions of the Creative Commons Attribution license (http://creativecommons.org/licenses/by/4.0/). 